\title{
LUNATICS AND LUNATIC ASYLUMS IN EARLY SINGAPORE (1819-1869)
}

by

\author{
Y. K. LEE
}

A BRIEP résumé of the establishment and administration of the Straits Settlements is necessary to the understanding of the developments to be described. In the seventeenth century, the English East India Company was ousted by the Dutch from the islands of the East Indies. The East India Company then decided to concentrate on India itself, and in 1763, after having defeated France, its main rival, Britain became the dominant European trading power in India. By the end of the eighteenth century, the East India Company began to take an interest again in the Malayan Archipelago for a number of reasons. There was a need for a naval base on the sheltered side of the Bay of Bengal from which the Royal Navy could operate during the North East Monsoon to protect British merchantmen in the Bay of Bengal and beyond. A British controlled port along the China trade route was also needed. The Straits Settlements were thus established for strategic, protective and economic reasons. They were later also used as convict settlements, mainly for convicts from India.

Sir Francis Light in 1786 took possession of Penang Island in the name of the British Government and renamed it Prince of Wales Island. On 28 January 1819 Sir Stamford Raffles landed in Singapore, chosen for its excellent natural harbour and strategic geographical position, and on 6 February 1819 the Union Jack was officially hoisted there. Finally, by the Anglo-Dutch Treaty of 1824, Malacca was transferred to the British in exchange for Bencoolen on the west coast of Sumatra. Thus by 1824 , the three settlements which later formed the Straits Settlements were already established. In 1826, they were incorporated into a Presidency, known as the Incorporated Settlements of Prince of Wales Island, Singapore and Malacca, with Prince of Wales Island as its capital. This 'independence' was short-lived, as the Settlements were degraded into a Residency under the Bengal Government in $\mathbf{1 8 3 0}$. In 1832, the capital was transferred to Singapore. Prince of Wales Island was also the headquarters of the Medical Department, where the Senior Surgeon in the Straits officially resided, and the main Medical Stores were kept. Each of the settlements had an Assistant Surgeon and medical subordinates to carry out the medical duties. The headquarters of the Medical Department was also moved to Singapore in 1835.

Since Prince of Wales Island (Penang) was founded thirty-three years before Singapore, and was the seat of Government in the Straits from 1786 to 1832, it is worthwhile to trace the developments and study the official policy regarding lunatics in Penang before dealing with Singapore. For the first twenty-eight years of its existence, Penang had no lunatic asylum. Insane persons were under the charge of the police. In 1814, the Sitting Magistrate, Mr. John James Eskine, wrote to the Governor 
about the necessity of having a separate lunatic asylum. ${ }^{1}$ This matter having been discussed by the Governor's Council, the Secretary to the Government replied on 19 May 1814, as follows: ‘. . The attention of the Board having likewise been drawn to your recommendation of a proper Asylum in the vicinity of the Hospital, for Insane Persons who are at present under the charge of the Police, the Governor-inCouncil in giving his sanction to a measure tending to the care as well as to the comfort of the individuals labouring under Mental Derangement, recommends that the Sitting Magistrate should adopt such measures as he may in his opinion deem most advisable for the erection of a building for the accommodation of the persons before stated. ...'2

This first lunatic asylum was built near the convict lines in the interest of economy and convenience, for the warders who guarded the convicts also looked after the lunatics. In May 1825, a committee which had been constituted to investigate the state of the convicts in the settlement, reported that ' a Mad House, in which there are now 22 lunatics, including only one convict, is situated in the vicinity of the Country Lines, which we also deem objectionable, and recommend that it be removed to a spot near the proposed new Hospital; that a Keeper and Establishment for the same be allowed, and that the Surgeon of the Convict Hospital be placed in charge, with a reasonable compensation for his trouble and supply of medicines. This Establishment, we think, should be placed under the general control and management of a Committee, similar to the Chinese Poor Asylum. . . .'3

Following this, on 18 November 1825, the Senior Surgeon was 'desired to suggest arrangements for the medical care and provision of necessaries for the unfortunate lunatics',4 and on 28 November 1825, he recommended that the general management of the Lunatic Asylum should be vested in a Committee consisting of the Superintendent of Police, the Senior Surgeon and the Chaplain, with authority to run the Asylum 'as they deem necessary for the good of the unfortunate objects placed therein'. He also recommended that the Surgeon of the Convict Hospital should be placed in charge of the Lunatic Asylum; the Overseer of Convicts should continue to be responsible for provisioning; and that there should be a separate establishment of subordinate staff, e.g. cooks, patients' attendants. ${ }^{5}$

Governor Fullerton recorded a minute on the Senior Surgeon's plan for establishing the asylum. He was more concerned with the financial implications. He did not agree to the proposal that a separate establishment of staff was necessary 'as it would be attended with much expense, and would form the certain ground of growing and increasing charge'. He favoured a lunatic ward in the vicinity of the General Hospital, under the charge of the Medical Officer of the General Hospital, who would be paid an allowance. He emphasized that a Lunatic Asylum was not a pauper institution, and that patients with means, should contribute to their own support. He suggested that for pauper lunatics 'means should be devised for levying from the community the contribution requisite for their support'. He approved the proposition that the Lunatic Asylum should be under the management of a committee, but insisted that the Accountant General should replace the Superintendent of Police, and that the Deputy Accountant should act as Secretary and Treasurer. ${ }^{6}$

The Lunatic Asylum was run on very economical lines, but soon the Assistant Surgeon in charge reported that he needed more attendants to look after the patients, 


\section{Y. K. Lee}

and more money to feed and clothe them. ${ }^{7}$ Eventually the government considered the maintenance of the Lunatic Asylum a financial burden, and stern measures were adopted. In February 1827, the Superintendent of Police was directed to inquire whether the lunatics supported at 40 Rupees per month had friends and relatives and whether they had property of their own. ${ }^{8}$ After due investigation, he reported that all the lunatics in the Mad House were paupers, and that those with relatives were being looked after at home. ${ }^{9}$

In June 1832, Lt. Nesbitt, a lunatic, arrived at Penang on his way to England. He was put on shore because the boat was leaky, and had to be sent to the Artillery Hospital, because the Lunatic Asylum was not considered suitable for Europeans. ${ }^{10}$

This briefly was the state of affairs in Penang from its foundation to 1832, when the seat of Government was transferred to Singapore. It is important to note that the policy, pattern and trends in development were repeated in Singapore.

Sir Stamford Raffles landed in Singapore on 28 January 1819, with a detachment of troops of the Bengal Native Infantry, and a Medical Officer, Sub-assistant Surgeon Thomas Prendergast in medical charge of the whole expedition. In May, Prendergast was joined by a more senior officer, Assistant Surgeon William Montgomerie, also of the Bengal Establishment. Their duties were both military and civil. Prendergast served in Singapore until 1823, and Montgomerie until 1827 when they returned to Bengal. Montgomerie returned to the Straits as the Senior Surgeon in 1832.

In June 1827, the medical duties at Singapore were divided between Surgeon B. C. Henderson, who had been sent from Penang, and Assistant Surgeon Warrand, who came with a new detachment of troops to relieve Montgomerie. Henderson was in charge of the General Pauper Hospitals and Warrand was responsible for the convicts and troops. There was no mention of a Lunatic Asylum as none existed. ${ }^{11}$

The acting Senior Surgeon, W. E. E. Conwell, came to Singapore in February 1828 on an inspection tour of the hospitals. He reported that an insane European was being treated in the Singapore Infirmary. ${ }^{12}$ John Hanson, a mad Dane, was less fortunate. He was confined in jail, as this letter written by the Superintendent of Police, Mr. S. G. Bonham, on 27 May 1828, to the Secretary to Government shows: 'I beg to bring to the notice of the Government that one John Hanson, a Dane, who has resided in this Settlement for about five years is subject to temporary aberration of mind, and that lately he has become much worse, so much so indeed that he is now in confinement, as there is no suitable place for people in his unfortunate state. I would respectfully request that he be sent to Calcutta or any other place where a Lunatic Asylum may be established.' 13

Even after Singapore became the capital of the Straits Settlements in 1832, and the headquarters of the Medical Department in 1835, there was no Lunatic Asylum. The insane were still kept in jail. Soon after his arrival in Singapore in 1835, Senior Surgeon Montgomerie received his instructions from the Governor: ' . . . I conceive it the duty of a Medical Officer to visit the Jail daily with reference to the number of Criminals and Insane persons confined in it. I do not anticipate any objection on the part of Mr. Oxley [the Assistant Surgeon] to continue the performance of those duties which have heretofore always been gratuitously and cheerfully afforded by himself and his predecessors.' 14 


\section{Lunatics and Lunatic Asylums in Early Singapore (1819-1869)}

There was no change in the system by 1837 . In fact, it was more firmly established, for in the List of Fixed Establishment for the Settlement of that year, special provision was allowed for the Sheriff's Department (not the Medical Department!) for the care of the lunatics: ${ }^{15}$

\begin{tabular}{ll} 
Gaoler & 25 Rupees \\
Overseer & 15 Rupees \\
2 Convicts & 10 Rupees [Convicts were used as public servants] \\
\cline { 2 - 3 } & 50 Rupees
\end{tabular}

Twenty years after the founding of Singapore, in 1838, there were beginnings of public agitation regarding lunatics. A letter appeared in the Singapore Free Press on 21 June 1838:

... You and many of your readers are aware that no Lunatic Asylum exists at any of the Straits Settlements, and that it is customary to confine in the Sheriff's Jail, our unhappy fellow creatures who are deprived of their reason. So long as no other place exists specially for them, the Jail is probably the best that could be selected. . . . I would respectfully suggest that the Grand Jury apply all the subjects of inquiry to the lunatics confined in public jails. . . . It has been proved that in recent cases of insanity under judicious treatment, as large a proportion of recoveries will take place as from any other acute disease of equal severity. It would be a waste of words to impute blame to any of the Straits authorities for not having long ere thus commenced a system of treating lunatics very different from criminals. What has passed is beyond remedy but it will be the fault both of men in power and of the whole community if a system based on the experience of Europe and America be not adopted hereafter.

The object of this letter is to direct public attention to existing modes of proceeding with these unfortunate creatures. If after investigation, the present mode is found to be the best, let it be by all means continued, but if improvements can be made, it is the duty of all good citizens to aid in carrying them into effect.

I cannot doubt the ready will of the civil authorities in the Straits to furnish every possible information on the subjects of inquiry proposed ... the sooner proceedings are instituted, the more information will there be to lay before the first Grand Jury that may enter on the investigations.

The Editor joined in the fray and wrote:

... the confinement of the unfortunate victims of insanity in the Sheriff's Jail without the slightest provision being made for their proper treatment calls loudly for improvement. A few months ago, there were, we believe, no less than seventeen of these unfortunate beings in the Jail. There is space enough in the hospital yard to construct a suitable building for their reception, and we hope the absolute necessity there exists for providing something in the nature of a Lunatic Asylum will not be overlooked.

It may be puzzling for the reader to learn that the Grand Jury was requested to investigate the condition of the lunatics in Singapore. One has to digress here to explain the function of the Grand Jury in early Singapore, which was different from that which is normally ascribed to Grand Juries in Criminal Courts.

Early in English legal history, the jury, according to Maitland was 'a body of neighbours summoned by some public officer to give, upon oath, a true answer to some question'. This system of inquiry was introduced by the Norman kings and was extensively used to supervise the activities of all government departments. It was used not only by the Central Courts, but also by the lower courts, where, e.g. in that of the Justices of the Peace, the jury continued to be used for general administrative 
purposes long after it had come to be used entirely for judicial purposes in the Central Courts.

The Courts of the Justices of the Peace (Quarter Sessions) were more than mere judicial courts. A jury was summoned, a general charge as to matters into which the jury must inquire was given and the jury made its presentment. By this process of presentment and indictment, the Quarter Sessions not only tried criminal cases, but also supervised the whole administration of the local government. In other words, the organization of the local government under the Justices of the Peace followed the old judicial models. It centred upon the Quarter Sessions, the business of which centred round the charge to the jury and the presentment which it made. It was, in fact, local government by judicial procedure. This was still the practice in England in the seventeenth century.

This jury system was introduced into India by the British in the seventeenth century, and from there to the Straits. Although strictly speaking, by the eighteenth century in England, a Grand Jury could only present on matters on which an indictment could afterwards be framed, the practice in the Straits persisted until the Grand Jury was abolished in 1873 . Hence the Grand Jury was intimately involved in the local administration of Singapore. In practice the Grand Jury received a charge from the Recorder during a criminal session in Court. They then made their investigations, which included visits of inspection. Their Presentment was finally made to the Recorder, who added his own comments, and sent the Presentment to the Governor. He, after studying the Presentment, called on his officials for explanations. Thus, the Grand Jury was not very popular with the Government officials.

Nothing came out of the public outcry, but things came to a head in October 1840, when a lunatic was murdered by another when both were confined together in the jail. The Governor, S. G. Bonham, immediately asked Senior Surgeon Montgomerie for a report on the number and state of the lunatics under treatment, and also for suggestions for their better management. ${ }^{16}$ Montgomerie reported on 16 November 1840 that there were nineteen insane patients confined in jail, and three who were 'quiet and inoffensive', in the Poor house. He expected the yearly average of seventeen patients under treatment at any single time to increase with the growth of the settlement. He recommended that a Lunatic Asylum should be built:

... that a substantial building with cells sufficient for the separate accommodation of 24 patients be built. The cells need not be more than 7 feet long and 5 feet wide, just sufficient to admit of a doorway and bed place. The building, I should recommend to be of brick walls and tile roofs, 60 feet long and 30 feet broad, having rows of cells in each side with grilled windows to give ventilation and a door to open into the space in the middle, which would be 60 feet long and 16 feet broad, and being open both ends would form a covered airy place for the unfortunate individuals in bad weather ... would be all that is necessary at present. If in future, more accommodation should become necessary, by adding to the length of the building, accommodation would be obtained for the patients. The floors of the cells should be laid with bricks on edge, embedded in good mortar so as to admit of being washed, and prevent the patients lifting the floors, which constructed with tiles as in the Jail, they have been enabled to do so. The walls of the cells should be constructed of stout planking, and the bed places of the same material, strong enough to resist the efforts of the patients to injure, which they might do so, with bare hands if weakly constructed. I have recommended wood for the walls and bed places in consequence of very bad effects having arisen from patients in the Jail having destroyed the bed places and by squatting on the floor and leaning against the cold walls, have in several instances cramped their limbs and stiffened their joints so as to cause lameness. ....' 
He recommended that the Building be placed in a small enclosure at the corner of the Poor House yard, and submitted a plan and estimate for $\$ 775.16$.

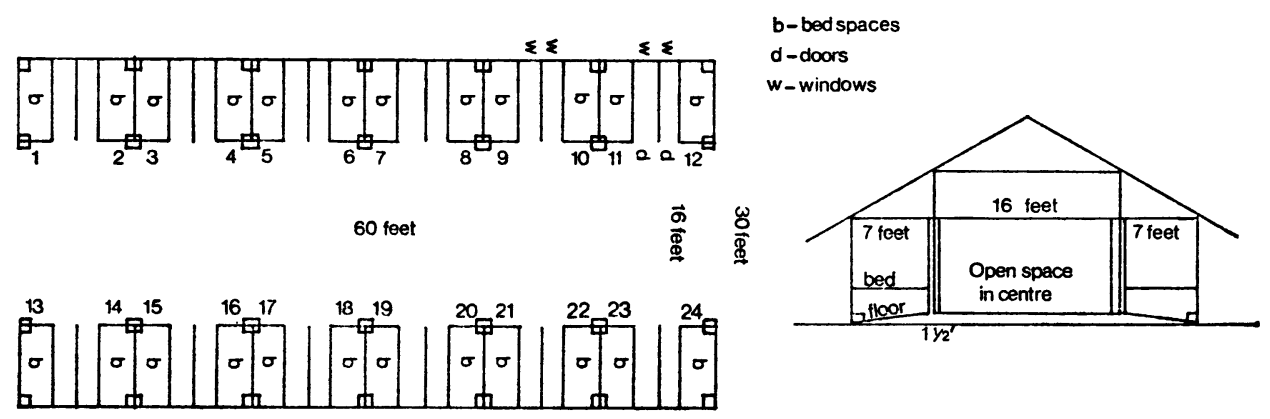

Plan of Insane Hospital proposed by Dr Montgomerie

Montgomerie did not favour the idea of sending the lunatics to India as the lunatics were all 'natives of the East-Chinese, Malays, Buggese and Javanese'. He was rightly of the opinion that 'they may be more comfortably provided for among their own countrymen than among strangers to their language and habits, provided there are suitable accommodation for them on the spot'.17

The Governor, on 28 November 1840, reported the incident of the murdered lunatic to the Government of Bengal, and recommended that a Lunatic Asylum on the plan suggested by Dr. Montgomerie be erected at Singapore it being necessary for the credit of the Government that a recurrence be prevented'.16 On the recommendation of the Military Board and the Medical Board at Calcutta, the Governor of Bengal approved of the plan and estimates of $\$ 775.16$, and transmitted the advice of the Medical Board 'that a piece of Ground as a place of exercise, and likewise, of occupation in those cases where the patients can be prevailed upon to employ themselves' be included as part of the Asylum. ${ }^{18}$ The Lunatic Asylum was built 'for the custody of the patients', and the same number of staff attended them as when they were in the jail: one Superintendent, one Dresser and two convict attendants.

For the next twenty-five years, the Grand Jury of Singapore played a very important part in influencing the management of lunatics in Singapore. The Grand Jury made nine Presentments on the Lunatic Asylum and the care of lunatics during these twenty-five years, and compelled the Government to improve conditions. After each Presentment there was a spurt of official activity, which the newspapers publicized. On 20 June 1844, the Singapore Free Press reported the Presentment made by the Grand Jury at the Criminal sessions, which was very critical of the Lunatic Asylum: - ... The Grand Jurors present that in the receptacle for the Insane attached to the Pauper Hospital, no means appear to be taken for the cure of the patients. The Building is insufficient; the cages or dens (whatever name they may deserve) being fewer than the patients. In many cases, two madmen are required to be placed together. ..'. 


\section{Y. K. Lee}

Governor Butterworth was annoyed when he read of this Presentment. He had expected some improvement in the Lunatic Asylum after his last visit. Colonel Butterworth was appointed Governor of the Straits Settlements on 14 June 1843, and soon after his arrival at Singapore, he went on a familiarization tour of government institutions. At the Lunatic Asylum, he 'found a poor attentuated wretch lying dead in one of the Dens, he having expired of Dysentery', and two other inmates completely naked and in so emaciated a condition as to be totally harmless, and whose removal to Hospital was forthwith commanded'. ${ }^{19}$ The Governor told the Resident Councillor in October 1844, that in the light of his personal experience, he concurred with the Grand Jury that no means appeared to be taken for the cure of the patients in the Lunatic Asylum. He ordered that the Asylum should be placed under the charge of the Senior Surgeon, Dr. Oxley, "whose duties are sufficiently light to enable him to give this Institution his fullest attention', and who was expected to submit a quarterly report on the condition of the inmates. Oxley was requested to write to Dr. Cantor, the Assistant Surgeon at Penang, to learn how the Asylum there was so efficiently managed. This was a slight as Dr. Cantor was Dr. Oxley's subordinate. Arising out of this, Oxley was also ordered to visit all gaols, convict lines and other places of confinement quarterly and to submit a report. ${ }^{19}$

Governor Butterworth continued his investigations and reform of the Medical Department at Singapore, and in November 1845, concluded it was necessary to prevent the medical officers from 'early falling into the laxity of discipline which evidently prevails in the Hospitals in Singapore', and he requested the Resident Councillor together with the Senior Surgeon to frame and submit for my approval a set of Rules for the admission, dieting, etc. for the inmates of the several hospitals in Singapore', and he also expressed the hope that 'the subsequent attention of the Senior Surgeon to the Lunatic Asylum will render that a credit which was a disgrace to the Settlement'. ${ }^{20}$ The first important step taken by Dr. Oxley to improve the lot of the lunatics, was to put a medically qualified person, Assistant Apothecary Henry Lloyd, in charge of the Lunatic Asylum, and for Lloyd to be personally responsible to him for the care of the lunatics. ${ }^{21}$ By February 1846, Dr. Oxley was able to report that the condition of the lunatics had improved. ${ }^{22} \mathrm{He}$ had introduced occupational therapy, and out of the proceeds of the work done, he had given each inmate two suits of clothes, and it is only from inability to procure sufficient employment of a suitable kind for them that has prevented us making them more comfortable'. There were thirty patients in the Asylum. Oxley introduced the system of non-restraint and attempted to alter the public's image of the Lunatic Asylum as a building whose 'sole object contemplated was the prevention of mischief to the public to the entire forgetfulness of the needful accommodation for the patients who were at first caged in their cells like so many wild beasts without clothes or any means of cleanliness ... . with a couple of convicts to keep watch to prevent their escape'. ${ }^{21}$ For his good work, Dr. Oxley was highly praised by the Governor. ${ }^{23}$

The public however were not easily satisfied. A patient, by name Kalloo, died on 11 February 1847, and his widow petitioned the Resident Councillor claiming that her husband had died of illtreatment. Oxley's report on 17 February 1847, throws some light on the management of lunatics then: 


\section{Lunatics and Lunatic Asylums in Early Singapore (1819-1869)}

The person alluded to was admitted by me into the Pauper Hospital at the urgent solicitation of two friends who brought him on the 25th November, 1846, labouring under Idiotic Insanity. He was admitted for treatment in the hope of benefiting him, and allowed to walk about the hospital free of any restraint, but occasionally he was shut up in the lunatic cells for escaping from the hospital compound. He continued in this manner neither getting better nor worse until the 6th instant when he was struck down with total paralysis for which he was actively treated by blisters and other counter-irritants, but without any good effect.

$I$ instituted a post-mortem examination and found that the paralysis had been produced by effusion on the brain, the result of long-continued inflammation of the membranes which were thickened and opaque. The brain was in a state of high congestion and appearances such as to render recovery in the circumstances impossible. I am positively certain there were no marks of a rattan on him, but the abrasion of blisters and counter-irritants might be easily mistaken by any ignorant person for ill usage. ${ }^{34}$

1847 and 1848 were uneventful years, except for a shortage of accommodation in the Asylum. There was an average of thirty-five patients and only sleeping berths for twenty-four, and the Senior Surgeon was compelled to discharge 'harmless' patients in order to make room for 'dangerous cases', but he was able to report that 'the system of non-restraint continues to work admirably. The men, when not employed, amuse themselves at games. They are apparently very happy, and when junk is procurable, set themselves to pick oakum with alacrity and cheerfulness. They have been clothed entirely from their own industry during the year; their earnings amounted to $\$ 90 /-$ for 60 piculs of oakum prepared by them; $\$ 45$ was laid out in the purchase of 154 pieces of clothes including Jackets and Trousers; and $\$ 1 /$ - expended in the purchase of a cask to steep the junk, so that there remains a balance on hand of $\$ 44 /$, which with the work obtained from time to time will enable us to keep them clean and tidy.'25

The indefatigable Dr. Oxley was always looking for means to supplement the income of the Asylum in order to alleviate the condition of the inmates. In addition to picking oakum, he introduced basketmaking. His most ambitious scheme, begun at the end of 1848 - was that of making gutta percha sheets for surgical purposes. He sold 180 yards to the Medical Board at Calcutta and, thus encouraged, he asked for a contract 'to furnish a constant supply at 10 per cent below the market price' as the sum realized would enable him to clothe the inmates, and 'to secure a more suitable building in a more appropriate situation than the present Asylum, which is situated in the yard of the Convict Hospital.' 26 He did not succeed as the Medical Board found that better quality gutta percha could be obtained elsewhere.

On 10 February 1849, Act IV of 1849, entitled 'An Act for the safe custody of criminal lunatics' was passed by the Indian Government. This Act also came into force in the Straits Settlements which were administratively part of India. It declared what unsoundness of mind excused the commission of criminal acts, and provided for the safe custody of persons found guilty of such acts, but acquitted because of unsoundness of mind. It was Singapore's first ever legislative enactment regarding lunatics, and the first person committed under the Act was a Chinese, Lim Say Soon: ${ }^{27}$

To the Sheriff, To wit

Whereas LIM SAY SOON on the 21st August, 1848 last past was indicted for murder, and whereas the findings of the Petit Jury was "not guilty being insane at the time of committing of 


\section{Y. K. Lee}

the deed', and whereas the sentence or judgement of the Court was that 'the said Lim Say Soon was to be remanded until further orders.'

Now as the said Lim Say Soon is still in an insane state, and it being provided for by Act IV of 1849 entitled 'An Act for the safe custody of criminal lunatics' passed by the Honourable the President of the Council of India in Council on the 10th February, 1849, it is hereby ordered in accordance with the 6th section of the said Act, and you are ordered to deliver up the body of the said Lim Say Soon to the Keeper of the Lunatic Asylum there, and there to be kept and treated as the Government shall order, and let this be your warrant.

(Sd) W. J. Butterworth, Governor, 13.6.1849.

Oxley's complaints to the authorities about the acute shortage of accommodation were ignored. On 11 April 1849, he wrote to absolve his staff from blame: 'This is to certify that there is no accommodation in the Lunatic Asylum for any more patients. The Keeper cannot possibly be accountable for any accident that may occur if more be sent. There are only 24 sleeping cots and already 37 patients.' 28

On 24 April 1850, the Grand Jury took up the cause of the lunatics again, when in its Presentment it drew public attention to the overcrowding at the Asylum, and to a skin disease suffered by the inmates: ' . . . The Jurors present that the inmates of the Lunatic Asylum appear to be suffering from a cutaneous disease, which has spread its contagion to almost every inmate in the building, and which appear to the Jurors to have been caused by the want of caution in the first stages of the disease, in separating the clean from the unclean. The Jurors found the whole of the inmates working in the same room and so close together, that contagion would be unavoidable. The Jurors recommend that the sleeping wards be whitewashed, and that the building generally receive that attention, which the occasion calls for. The Jurors are of the opinion that the building is on too small a scale for the purposes required.' ${ }^{29}$

When the Senior Surgeon was asked for his report, he took the opportunity to reiterate that the building was inadequate and 'very ill adapted' for the treatment of the patients. The overcrowding had caused at least fourteen patients to suffer from 'itch', for which they had been treated, but he was of the opinion that there could be no cure as 'the floor is so undermined by numerous rats, the vermin from which, sadly plague the patients and tend to keep up and produce irritation of the skin.' The only solution was 'an entire renewal of the building, which at the same time might be remodelled and enlarged.' He felt that his staff should not be blamed for the shortcomings of the authorities, and that credit was due 'for the good effected with such slender means than blame for anything that may have been omitted,' and asked for a complement of staff similar to that of an asylum in Bengal. ${ }^{30}$

The Governor on 17 May 1850, ordered the floor of the Asylum tiled and the walls whitewashed as a temporary measure, and instructed the Superintending Engineer and the Senior Surgeon to furnish 'a report as to the best means of increasing the accommodation for the inmates with an estimate of the expense of the same. ${ }^{31}$ The Superintending Engineer in consultation with the Senior Surgeon, submitted a plan for a building large enough to accommodate twenty-four patients near the old Asylum, and suggested that 'the patients be divided into two classes: those whose insanity is at times of a violent character, being assigned to the old building, where restraint rooms are already in existence; while the new hospital should be appropriated for the reception of idiots and patients whose malady is likely to yield to medical 


\title{
Lunatics and Lunatic Asylums in Early Singapore (1819-1869)
}

treatment'. The estimated cost of the building was 1231 Rupees 11 Annas 8 Pice. The plan and estimate were submitted to the Goverment of Bengal and approved on 9 August 1850, thus increasing the accommodation of the Lunatic Asylum from twenty-four to forty-eight. ${ }^{32}$ The Grand Jury, however, were ever vigilant. On their visit to the Lunatic Asylum on 19 September 1851, they noticed that 'employment to inmates of the Lunatic Asylum appears discontinued. ${ }^{33}$ The Senior Surgeon, obviously annoyed, explained to the Governor that where occupational therapy and contract work were concerned, 'materials are not always procurable to furnish suitable work to the inmates, which was the case on the occasion of the visit of the Grand Jury in September last. ${ }^{34}$

A short description of the life of the lunatics in the 1850s will give an insight into the conditions then prevailing.

\begin{abstract}
The inmates are made to exert themselves not only in picking oakum, but in cleaning their dormitories daily. They have a well to bathe at and have exercise given to them in the compound. They breakfast at 9 a.m. of rice, curry and fish, and have their dinner at 3 p.m. of the same description. They change their clothes once a week, getting a clean suit every Sunday. Whether sick or well, all are compelled to take purgative medicines once a month; and those with any peculiar ailments have specific treatment. Patients when first admitted have some active treatment, e.g. counter-irritation to the back of the head by blisters and Tartar Emetic ointment followed by a seton, accompanied with the administration of Belladonna, Morphia and Tartar Antimony internally. With respect to the treatment of the patients when under peculiar excitement, which comes on from time to time with many of them, they are pro tempore shut up in their cells, and get morphia, belladonna and such soothing medicines. Except during these periods of exacerbation, there is no restraint whatever exercised towards them. ${ }^{85}$
\end{abstract}

Europeans were not admitted to the Lunatic Asylum which was considered unsuitable for them. They were sent to the European Seamen's Hospital, where they created serious problems, as shown in this letter written on 25 June 1850 from the Medical Officer in charge to the Resident Councillor: 'A man, George Fox, admitted by you on the 20th ultimo is quite of unsound mind. He severely struck the Chinese Toty [attendant] who can hardly be induced to remain, and the other patients are afraid of him. We have no means of properly confining or efficiently watching him. I consider his presence here seriously detrimental to the comfort and peace of the patients and of the establishment generally' ${ }^{36}$ As a result of this incident, the Medical Officers were authorized to admit, at their own discretion, European patients into the Lunatic Asylum, which by 1852 had forty-nine patients and only three elderly convict attendants to look after them. This policy of admitting and confining Europeans in the Asylum together with the natives was not wholly acceptable as it was considered infra dignitatem. When Dr. Oxley admitted a Frenchman, Louis Allard, in February 1852, the French Consul protested to the Governor! Since there was no 'Lunatic Asylum in Singapore calculated to receive an European, and especially an European addicted to violence', the very few European patients were sent back to Europe by the first available boat unless they happened to be paupers, e.g. shipwrecked sailors.

On 17 August 1853, the Grand Jury once again found fault with the Lunatic Asylum. They presented that there was irregularity in the admission and transfer of patients to the Lunatic Asylum which was used as a place of punishment, and condemned the old building (the original one) in the Asylum, and recommended that it be pulled down: 


\section{Y. K. Lee}

... The Jurors would call your Lordship's attention to the great want of system shewn in transferring persons from the Sick to the Insane Wards. It seems that no medical certificate is ever given for such transfer, and the power of placing patients in this part of the building appears to rest solely with the person in charge. So far as can be gathered from statements made in answer to inquiries, it appears that at the present moment, three convicts are now in the Insane Ward, who have been placed there as a punishment by the Superintendent of Convicts for disrespect in the Lines-a most undesirable arrangement.

The Jurors present that the sleeping places for the violently Insanes are in a most dilapidated and filthy condition; originally far too small and ill-arranged, and now decayed, badly kept and worse ventilated, these dens (for they can be called nothing else) are in a state that the Jurors can recommend nothing else than that they should be forthwith pulled down and destroyed, and that some special and suitable accommodation should at once be provided for these unhappy beings. .... ${ }^{37}$

Senior Surgeon Oxley was really angered this time. He 'regretted that that body to whose opinions such importance is usually attached, should have made assertions before ascertaining the correctness of the facts'. Lunatics could only be admitted by the order of the Senior Surgeon or the Superintendent of Police. The Superintendent of Convicts had no authority to admit patients. All insane convicts were seen by the Senior Surgeon before admission. Dr. Oxley was so tired of being criticized when he was doing his utmost to run the Asylum with the little means at his disposal, that he wrote to the Governor, 'If the establishment and accommodation be deemed insufficient for the wants of the community, I respectfully suggest that it is for the community and not the Government to provide the means of improvement and I can only say in conclusion that it will afford me great pleasure in giving my best attention to seeing any means placed at my disposal for that purpose used to the best advantage.'38 This challenge was not taken up until three years later. In the meantime, to make matters worse, lunatics from Malacca were transferred to Singapore for treatment, ${ }^{39}$ and when Oxley asked for more subordinate medical staff and attendants, his requests were turned down.

A few months before his retirement, Dr. Oxley wrote on 7 April 1856 to the Government urging action regarding the Lunatic Asylum and the care of the lunatics. He was less polite this time, and drew attention to the fact that there were seventy-five patients in buildings intended for forty-five at the most. Of these, two were murderers who required strict isolation and four were women who needed separate cells. 'The requirements of the establishment are far beyond what it professes, and a steady reorganisation is imperatively called for. The present place is a makeshift and never has been other than such, as I have frequently represented. But to enable his Honour to come to some definite opinion on the subject, I beg to call his attention to the Rules \& Regulations laid down for Lunatic Asylums throughout Bengal, to be found in the Bengal Medical Code, pages 251-253, wherein ample provision is made for the management and care of such establishment.' $40 \mathrm{~A}$ fortnight earlier, on $26 \mathrm{March}$ 1856, the Sitting Magistrate, Mr. Dunman, had tried to persuade the Municipal Commissioners 'to go to the expense' of a ward for female lunatics, only to be told that 'it is not within their province to grant it, it being a Government and not a Municipal duty'. The Government, however, did not consider it its duty either. ${ }^{41}$

Despite public comment in the newspapers regarding the 'non-existence of any public provision for the proper custody and treatment of insanes', there was no 


\section{Lunatics and Lunatic Asylums in Early Singapore (1819-1869)}

Government action until prodded by a donation by two Chinese merchants, Low Joon Teck and Chung Sam Teo, who were the Opium Farmers, i.e. they had the Government monopoly to sell opium in Singapore. On 28 May 1856, they wrote to the Governor and placed $\$ 3600$ at his disposal 'to be employed in the erection of some building that will be of permanent utility and advantage to the poor classes of this Island, and mark in a small way the interest we feel in this prosperous island'.42 The Governor immediately wrote to India on 12 June 1856, regarding the necessity for enlarged and improved accommodation for lunatics at Singapore and informed the Indian Government that he proposed to build a medical complex which would include a new General Hospital, Lunatic Asylum, Medical Stores and Dispensary, and that the donation of the Chinese merchants would be used for erecting the Lunatic Asylum, Medical Stores and Dispensary. In the meanwhile, the Executive Engineer was ordered to prepare the plans and estimates of this medical complex. The Indian Government approved this proposal in October 1856, with two modifications. The Governor-General had decided that the Lunatic Asylum should be built with Government funds because it was an object 'for which everywhere the Government itself undertakes wholly to provide, and that no part of the very handsome donation offered by the Chinese merchants should be diverted for the purpose'. The whole donation was to be used to build the General Hospital. The Medical Board had advised the Governor-General that the Lunatic Asylum should be entirely separate from the General Hospital, and this recommendation was transmitted to Singapore. ${ }^{43}$ The plans and estimates were sent to India in February 1857, for approval. ${ }^{44}$ By a twist of fate, the decision to use Government money (\$9496) to build the Lunatic Asylum, instead of hastening, further delayed the building of a new Lunatic Asylum at Singapore. When the Indian Mutiny broke out, all Government spending was curtailed. Only works of military importance were sanctioned, and those that involved 'unnecessary expenditure' were shelved, and this latter category included the Lunatic Asylum. Work on the General Hospital, however, started in the Kandang Kerbau district, where the whole medical complex was eventually built.

In 1857, an Army surgeon temporarily took charge of the Lunatic Asylum at Penang when the Surgeon in charge was away. When he was not paid his share of the 'Dieting Allowance', he complained. The inquiry which followed brought to light a system of feeding the inmates of the Asylums of Singapore and Penang, which was subject to abuse. ${ }^{45}$ This practice had been in force since the first hospitals and asylums were built in the Settlements. In 1857, the established practice was briefly like this: the allowance for dieting patients approved by Government was 6 cents per day, and at the beginning of each month the Medical Officer advanced $\$ 30$ from his own pay for purposes of buying rice, fish, etc. On the 15th of the month, he billed the Government for the monthly allowance calculated on the number of patients in the asylum on that day. From this sum, he recovered his $\$ 30$ and any surplus above that required for dieting the patients for the month. This right to appropriate any surplus of the dieting allowance was considered 'a perquisite of the surgeon in charge, sanctioned by established usage', because there was always a possibility he would lose if there were more patients before than after the 15 th of the month. In practice, what usually happened was given in evidence by a medical subordinate 'I was instructed 


\section{Y. K. Lee}

to feed the patients on $4 \frac{1}{2}$ cents per day, the remainder going to the surgeon in charge'. In December 1857, the Governor General ordered the practice to be stopped. ${ }^{46}$

Since there were no funds to build a new Lunatic Asylum, the old one was repaired and 'rendered as complete and comfortable as the limited space set apart for it would admit of'. But more and more patients were admitted. The police sent many who were suffering from 'temporary excitement caused by the use of Ganjah [marihuana] or other Narcotics, and remain, for want of proper securities, a considerable time in the Asylum'. 7 By the end of 1858, there were eighty-six patients under treatment, and as a temporary measure, some were placed in the jail. This was discovered by the Grand Jury in January 1859 , and there was another hue and cry. ${ }^{48}$ The situation was quite intolerable for the medical authorities. Fortunately, on 14 September 1858, 'An Act relating to Lunatic Asylums' (Act XXXVI of 1858) was passed by the Indian Government which also came into force in the 'Stations of the Straits Settlements'. The preamble stated that it was 'expedient to provide for the reception and detention of Lunatics in Asylums, established for that purpose'. The main provisions of the Act were:

(1) Government may establish Lunatic Asylums, which shall be managed according to rules, and have Visitors.

(2) The appointment, duties and powers of Visitors.

(3) The Police to apprehend lunatics, and bring them before a Magistrate or Commissioner of Police, who may commit to Asylum, unless friends or relatives are willing to be responsible for them.

(4) The Order (Form B) and the Medical Certificate (Form A) necessary for reception into an Asylum.

The Singapore Government found that it was not possible to carry out the provisions of Act 36 of 1858 as the existing facilities were inadequate. ${ }^{49}$ As the Act authorized the establishment of Lunatic Asylums, an appeal was made to the Governor General to rescind his order and to sanction the erection of the contemplated Lunatic Asylum. ${ }^{50}$ By April 1859, the number of lunatics had increased to 106 and the Grand Jury drew attention to the fact that because of inadequate accommodation, a number of them had to sleep in the workroom without any supervision, thus endangering their lives. ${ }^{51}$ Because of shortage of space, lunatics from Malacca were not welcome, and the Medical Officers at Malacca asked the Governor for sanction to erect an Asylum in Malacca in September 1859. This was not approved, for by then, there were indications that the Governor General would not withhold his sanction for the erection of the Singapore Asylum much longer. Plans had been made for the Lunatic Asylum in Singapore to cater for the needs of the whole Straits Settlements. 'Whilst it is in many respects desirable that all Insanes throughout the Straits should be sent to an Institution especially appropriated for the reception of patients of this description where they will be subjected to an uniform course of treatment under the supervision of the Senior Medical Officer, an arrangement not only likely to be attended with beneficial results as respects the number of recoveries effected, but also prove far more economical than the system of establishing a small asylum at each of the different Stations'.52

In November 1859, the Chief Engineer was ordered to commence work on the new 


\section{Lunatics and Lunatic Asylums in Early Singapore (1819-1869)}

Lunatic Asylum, and to complete it 'with the least practicable delay'. ${ }^{53}$ There were, however, delays as more funds were required as additions and alterations were found necessary during the construction, e.g. certain arrangements of divisions and partitions in the Asylum required by the Senior Surgeon. Another hitch was the water supply. The Chief Engineer wrote in February, 1860, 'The water supply . . . was never estimated for, it having been supposed that water could be got by digging on the spot, which is the case, but of a very bad quality as to the smell. I have endeavoured to sink a well down through the peat and black quagmire on which the building is constructed, and got as far as sand and obtained water clear in appearance but still offensive in smell. I hope by persevering a few feet lower that good water may be got, and the necessity of procuring water at so apparently large a cost as 2362 Rupees be avoided. . .' ${ }^{54}$

In the meantime, the Grand Jurors in April, 1860, presented that of the 121 patients in the Lunatic Asylum there was one woman. There was no proper accommodation for females and they suggested that this omission be rectified. 'They were much shocked to find an unfortunate woman, a confirmed maniac, confined in one of the small cells and exposed to the view of the other inmates of the Asylum. The Jurors trust no time will be lost in completion of the new building. . . .55 The Senior Surgeon supported their recommendation, and asked for a separate ward to be built 'for the confinement of lunatics of a higher class', and a 'small but separate compound may be set apart for such cases in the New Asylum'. ${ }^{56}$ This was not sanctioned.

The problem of obtaining drinking water was partly solved by October 1860 , 'good water having been obtained by working wells in the neighbouring sandy ridge [pematang], whilst since measures have been adopted for keeping out the surface water, and penetrating to the stratum of argillaceous sand below the upper bed of peat, the water found in the well originally sunk in the hospital compound has much improved, and will be found extremely useful for bathing purposes even if it should be considered unfit for drinking'. ${ }^{7}$

With all the delays, 1860 did not see the completion of the new Lunatic Asylum. On January 1861, the Grand Jury again presented 'the Lunatic Asylum as being a disgrace to the Settlement'. This time, they did not comment on the inadequate accommodation, 'understanding that the Government have a new building approaching completion', but concentrated on patient care. 'The neglect apparent in the treatment of the unfortunate inmates calls for the severest censure. The visit of the Jurors occurred at the dinner hour, when a disgusting mess of black rice and fish was being served out to Europeans and Natives alike, in a manner unfit for human beings' ${ }^{58}$ The Resident Councillor immediately assembled a Committee to inquire into the alleged bad state of the Asylum. The Committee visited it, inspected the food and deemed it wholesome, and from the appearance of the inmates considered them to have been well-fed. ${ }^{59}$ They concluded that there was no justification for the sweeping statements and severe strictures of the Grand Jury. The Senior Surgeon went so far as to challenge the Jurors to find healthier men under similar circumstances. This time the Governor supported his officials. He also blamed the community for their indifference, and was soundly criticized by the press for his statement: 'That the present Lunatic Asylum is a disgrace to the Settlement cannot be denied, but for 


\section{Y. K. Lee}

this disgrace, a certain amount of blame is attached to the community at large, who must have been well aware that the want of funds alone prevented the local authorities from authorising the erection of a more suitable building, and should therefore have come forward with liberal contributions to aid in the advancement of a work of real charity'.60 The Governor had apparently forgotten the donation of the Chinese Merchants. One good came out of the inquiry. The Governor came to know of 'the system at present in force at Singapore, under which the patients of the Asylum as well as other charitable institutions are dieted by the Medical Subordinate attached'. He ordered that the food supply for patients in the various hospitals should be either through a Contractor or through the Commissariat Stores. ${ }^{61}$ The supply of patients' food now entered its third stage, i.e. supply by an outsider (not the medical officer nor the medical subordinate) who was awarded the contract on the basis of tenders. This system too was subject to abuse.

The new Lunatic Asylum was completed in May 1861. The Senior Surgeon wrote to the Secretary to the Governor on 23 May 1861: 'I have the honour to report for the information of the Governor that the Lunatics were removed this morning from the Old to the New Asylum.' ${ }^{62}$ The Senior Surgeon was apparently quite satisfied with the Asylum, for he reported, 'The Buildings are very well arranged and great attention has been paid to ventilation. The cells are lofty and spacious, but the grounds around the building need draining. We are now laying them out and inducing the patients to assist'. ${ }^{63} \mathrm{He}$ also started planting trees 'which will shade the buildings and protect the patients from the sun'. He soon found that thirteen attendants were insufficient for the new Asylum and had to ask for three more convicts 'until the insanes can be taught to do some work'. The public were also satisfied. There were no complaints or dissent when this article appeared in the Straits Times of 7 September 1861:

... The Buildings which stand on the borders of the Race Course comprise the Seamen's, the Police and the Lunatic Hospitals, and have been constructed with all the improvements and conveniences which time and experience have suggested. ... .

We now pass on to the enclosure surrounding the Lunatic Hospital which are exactly counterpart in size and outward appearance to the two buildings we have already described [the Seamen's and Police Hospitals]. The larger building is allotted to those suffering from the milder forms of derangement. Here everything is kept in the most perfect order and cleanliness, and all appear to be comfortable and well-cared for. The smaller building is divided into cells for the confinement of the more dangerous lunatics. These cells are small but clean and well-ventilated.

It is a strange sight to see the imbeciles of so many nations mixed together. All seemed to be more or less happy. Some have laid out small patches of ground as gardens, and they take great delight in keeping them in order, and are most scrupulous in protecting them from their more mischievous fellow sufferers.

We were at first surprised to find that the accommodation for the lunatics took up as extensive buildings as both the other hospitals, but to hear that the number of lunatics are nearly treble that of all the other patients, we cease however to be astonished at this, when we reflect that the tenants of our medical hospitals, in most cases, recover and are discharged within two or three months of their entry, whereas mental maladies while seldom fatal, are generally permanent, and we meet in the Lunatic Asylum, not the cases collected during a number of months, but the accumulation of years. ...

However, by January 1862, the Senior Surgeon was already asking for modifications to be made to the Asylum to accommodate Europeans. 'There are at present two 


\section{Lunatics and Lunatic Asylums in Early Singapore (1819-1869)}

Europeans under treatment, and one Armenian female suffering under incurable Nymphomania. The accommodation for such cases is very bad, surrounded as they are by natives of all classes, and occasionally confined near criminal lunatics. At a trifling cost to the State, a portion of the compound might be walled off, and accommodation built for some eight patients'. There were 127 inmates under treatment then, 'employed at making bamboo blinds, in picking oakum; others in the garden, and in keeping the dormitories and grounds in order. Generally speaking, they work cheerfully especially when encouraged by a small allowance of tobacco or present of fruit'.64

By March 1862, the grounds of the Asylum were already tastefully laid out with shrubs, flower beds and grass plots, and the Asylum considered to be in excellent order, when cholera of a most fatal type broke out there. Forty-one out of the 127 patients fell victims to the disease and twelve died. This was regarded as a small mortality by the Senior Surgeon, 'when we consider the class of patients; many refuse all medicines; some requiring to have a dozen persons to force them to take their medicines'. He was at a loss to account for this outbreak, for 'at the time, the buildings and premises around were in perfect order', but he thought that the cholera was 'caused by the great heat and protracted drought we lately experienced succeeding unusually wet weather. It may be that the subsoil is faulty and needs to be thoroughly drained.' This he asked to be attended to immediately. ${ }^{65}$ The water supply could have been the cause of the cholera. Although wells had been sunk in the neighbouring sandy ridge, pure drinking water was not obtained because of percolation of surface water through the conduit bringing the water to the Asylum. Water was filled in large casks which were rolled along the road to the Asylum, damaging the roads in bad weather. By the end of 1862, the defects in the masonry aqueduct were repaired, and excellent water was conveyed into a large covered reservoir in the compound, and pumped into pipes by the patients themselves. This enabled the shower baths to be fully used too, 'a source of universal benefit to all the patients and a potent auxiliary in the treatment of the insane'. ${ }^{68}$ The prevailing types of disease were mania and monomania. Many of the former were caused by the use of narcotic drugs and were much more amenable to treatment, which was 'the use of the shower bath or cold douche, a careful regimen, the free use of antimony with salines and kind treatment'.

In June 1863, it was decided to implement fully the provisions of the Lunacy Act (Act 36 of 1858) and the Resident Councillor, the Commissioner of Police, the Executive Engineer, the Residency Assistant Surgeon and Police Magistrate were appointed Visitors to the Lunatic Asylum ex officio. ${ }^{67}$ This Act gave wide powers to the police to admit patients to the Asylum, and as a result many 'old emaciated Chinese' and men 'perfectly moribund from chronic disease and want' were admitted. The police were hard pressed to clear the streets and markets of vagrants and those abandoned by their relatives, and found their powers under the Lunacy Act very useful! Not so the Senior Surgeon who reported that in 1864, there were sixty-nine admissions, forty-six discharges and thirty-seven deaths and 'the mortality has been greater than usual; in many cases, the patients have been almost in a moribund state when brought to the Asylum and sunk from sheer exhaustion'. ${ }^{68}$ In 1865, the average number of inmates was 128 , and there were twenty-five deaths, 'nearly all of them 


\section{Y. K. Lee}

were admitted in a more than usually filthy emaciated moribund state'. ${ }^{60}$ Overcrowding soon became a problem, and orders were issued to medical officers 'to cause a placard to be suspended in every ward ... . shewing the number of cubic and square feet contained in the ward, the number of patients it is calculated to hold, and the number of patients actually admitted, .... with a view to enabling any overcrowding to be at once detected, and when practicable remedied'. ${ }^{70}$ To make matters worse, the Governor ordered the number of convict orderlies reduced from fifteen to thirteen in March 1865, and modified their duty hours: 'all should be present from 6 p.m. to 8 a.m. One-third should be allowed during the day to absent themselves from their posts for cooking purposes'. ${ }^{11}$

Although the Lunacy Act, section 7, empowered the authorities before admitting a lunatic into the Asylum, to require the friends and relatives, who can afford to, to pay for the expenses 'which may be incurred for the lodging, maintenance, clothing, medicine and care of the lunatic', in practice, only a very few patients paid for their stay. The Government bore the expenses of running the Asylum. In 1865, the lowest tender for the supply of provisions and firewood was 16 cents per day for each European patient, and 6 cents per day for each native patient. Rice was supplied by the Government Commissariat Stores. ${ }^{72}$

The Grand Jury made their last Presentment on the Lunatic Asylum on 18 October, 1865: ' . . . the cells resemble places of punishment rather than cure, and contrast most unfavourably with those in the Convict and H.M. Jails, which are intended for the former purposes only. The Grand Jurors would also suggest that the sleeping benches in the female ward of the Lunatic Asylum be removed. They occupy space which might be more usefully distributed. Part of the foundation of this building has given way, and in some instances, the walls have cracked. . . '73 This time the Grand Jury was ignored by the authorities. Grand Juries in India had just been abolished, and the local authorities saw in this the coming demise of the local Grand Jury (which was abolished by Ordinance VI of 1873 passed on 9 September 1873).

In January 1867, it was proposed that a nurse should be employed in the Lunatic Asylum. This was approved, and for the first time in Singapore's medical history, a female employee worked in the Medical Department. Her salary was 22 Rupees a month, and the reasons for employing her were: 'The Nurse, though attached to the Lunatic Asylum, would be required to attend equally upon the patients in the adjoining General Hospital as upon Insanes. At present, the only attendants at both Establishments are male convicts. There are always at one or the other of the two institutions, patients in the female wards, and it is consequently highly desirable for many reasons that a nurse should be entertained for the purpose of taking charge of them'.74

Since the Grand Jury had been snubbed by the Executive authorities, the press took upon itself the duty to criticize and express public opinion on the management of the Lunatic Asylum, among other things. The first opportunity came on 1 March 1867, when two lunatics escaped. These two men were confined in the Asylum for murder while of unsound mind. For months they had made themselves useful to the Superintendent in tailoring, gardening and controlling their fellow inmates. A cowkeeper, whilst admitting the Superintendent's cows, had left the back gate open, and 


\section{Lunatics and Lunatic Asylums in Early Singapore (1819-1869)}

the men escaped. The Daily Times wanted to know whether this was a preconceived plan. 'This matter ought to be inquired into; also the system of keeping soundminded men at the expense of the public for the benefit of the Superintendent in the duty of tailoring and picking oakum'. ${ }^{75}$ The railing around the grounds of the Lunatic Asylum was immediately strengthened. The Governor ordered stricter security measures: 'All criminal lunatics should be kept in irons, and their employment outside the compound wall on any pretence whatever, strictly prohibited. When the lunatic had been confined for some time and appears quiet, the irons should be of a light description such as mere ankle irons'. The police were to be informed immediately a lunatic escaped. ${ }^{76}$

The administration of the Straits Settlements was transferred from the India Office to the Colonial Office on 1 April 1867, and the Settlements became Crown Colonies, and had a new Governor, Sir Harry Ord. The transfer was long sought after by the inhabitants of Singapore, especially the mercantile community, because they felt that the Indian Government did not have their interests at heart. It had an impact on the Medical Department. On 18 December 1867, the Secretary of State for the Colonies instructed the Governor to submit replies to certain questionnaires on Hospitals and Lunatic Asylums. ${ }^{77}$ The Governor replied on 5 June 1868, that he considered the Hospitals and Lunatic Asylums to be properly managed establishments, and informed the Secretary of State that it was intended to use the Lunatic Asylum at Singapore as the hospital for the treatment of all cases of pauper lunacy in the Straits Settlements. ${ }^{78}$ On 18 May 1868, he had mentioned this to members of the Legislative Council. ${ }^{79}$ An analysis was prepared from the information supplied by the Governor, and he was informed by the Secretary of State on 12 November 1868 that 'the state of the Hospitals and Asylums is not such as would have been inferred from a perusal of your despatch'. He was instructed to ascertain for himself the state of the hospitals and to submit a report. The Lunatic Asylum was criticized for the following points: 'The Lunatic Asylum of Singapore consists of four large wards, each capable of holding 25 patients, and 14 cells. One of the wards is going to be broken up into cells. This is probably an inexpedient measure, but the attendants of a Lunatic Asylum would always be anxious to put as many patients as possible into cells, because they are thereby saved the trouble of pacifying the troublesome.' The fact that the attendants were convicts was also criticized, as were the means of restraint employed, handcuffs and tying to the bed, and the fact that no records were made of such restraints. It was also pointed out that there was no resident doctor, 'a condition which the highest authorities say is indispensable to efficiency'. ${ }^{80}$ The Governor protested about the 'unwarranted assumptions', and was told on 7 July 1869 that there was no intention to charge the medical authorities with a want of principle or neglect of duty. The purpose of the criticisms was to indicate the standard of care expected. Henceforth the Lunatic Asylum was to be managed according to the rules and principles set out in the Digest on Colonial Hospitals and Asylums, a copy of which had been sent to Singapore on 18 December 1867. This digest had been published on 14 January 1867 by the Colonial Office with the assistance of the Royal College of Physicians and the Commissioners in Lunacy. The Secretary of State added 'What has been the desire of Her Majesty's Government is that the Colonial 
authorities concerned should make themselves thoroughly conversant with these rules and principles; should bring the institutions for which they are responsible into conformity with them when conformity is practicable, and should explain the grounds on which they consider in any particular that conformity to them is impracticable or inexpedient owing to local circumstances, taking care always that the conclusions derived from a wide and cumulative experience of such institutions dealt with by the highest professional and scientific authorities in the Empire should not be too lightly set aside in deference to local or individual opinion'.81

The financial aspects of running the Asylum more efficiently, professionally and otherwise, however, had to be solved by the local authorities. Fixed hospital charges were introduced, and the police were reminded of their duties. The Colonial Secretary sent a circular to the Commissioner of Police on 11 August 1869:82

Commissioners of Police will in all cases where lunatic patients are admitted into Asylums upon their recommendation, enquire and report whether their friends are able to pay for their subsistence, and in such cases, will inform the relatives of the patients that the following rules have been framed by Government for the maintenance of the Lunatic.

For European patients-30 cents per day.

For Native patients-15 cents per day.

Payment at these rates to be made monthly in advance.

By His Excellency's command,

R. MACPHERSON, Colonial Secretary, Straits Settlements.

In Britain, during the fifty years under review (1819-1869), there was a period when lunatics, especially the paupers, were ill-treated. There were scandals and inquiries which revealed a cruel state of affairs. This was followed by an awakening of social conscience and reform for more humane treatment of lunatics, culminating in the passing of Shaftesbury's Act. By comparison, the conditions at Singapore, which was considered a 'remote outpost', were not too bad, and her doctors and leading citizens were enlightened men. Shaftesbury's Act (An Act for the Regulation of the Care and Treatment of Lunatics) was passed on 4 August 1845. By it, many safeguards were written into the law for the welfare of lunatics, e.g. a permanent Lunacy Commission; records of admissions, deaths, Visitors' visits, doctors' visits and case books were to be rigidly kept; a specified Order and medical certificate were required before a patient could be admitted; lunatic asylums had to have printed regulations, and their medical attendants had to be registered.

The law in force in Singapore at the time of the transfer was the Indian Lunacy Act of 1858. This Act was a simplified adaptation of Shaftesbury's Act. The Colonial Hospital Digest, however, had incorporated the spirit of the provisions of the English Act, and that was the standard expected after 1869.

\section{REFERENCES}

S.S.D. = Straits Settlements Despatches, 1867-1915.

National Library Holdings on Microfilm, Singapore.

S.S.R. =Straits Settlements Records, 1800-1872.

National Library Holdings on Microfilm, Singapore.

1. S.S.R., I 15. 19.5.1814.

2. S.S.R., I 15. 19.5.1814. 
3. S.S.R., H 14. 10.5.1825.

4. S.S.R., A 23. 8.12.1825.

5. S.S.R., A 23. 8.12.1825.

6. S.S.R., A 21. 15.12.1825.

7. S.S.R., A 70. May 1830.

8. S.S.R., A 32. 15.2.1827.

9. S.S.R., A 33. 19.3.1827.

10. S.S.R., U 2. 29.6.1832.

11. S.S.R., V 2. 8.6.1827.

12. S.S.R., A 51. 28.2.1828.

13. S.S.R., A 53. 27.5.1828.

14. S.S.R., AA 7. 1835.

15. S.S.R., V 7. 1.11.1837.

16. S.S.R., R 6. 28.11.1840.

17. S.S.R., W 5. 16.11.1840.

18. S.S.R., S 8. 17.2.1841.

19. S.S.R., Z 17. 15.10.1844.

20. S.S.R., U 11. 21.11.1845.

21. S.S.R., BB 80. 30.4.1850.

22. S.S.R., B 63. 20.2.1846.

23. S.S.R., U 12. 23.4.1846.

24. S.S.R., BB 67. 17.2.1847.

25. S.S.R., W 13. 29.4.1848.

26. S.S.R., R 18. 26.12.1848.

27. S.S.R., V 14. 13.6.1849.

28. S.S.R., BB 76. 11.4.1849.

29. Singapore Free Press, 26.4.1850. Microfilm. National Library, Singapore.

30. S.S.R., BB 80. 30.4.1850.

31. S.S.R., U 20. 17.5.1850.

32. S.S.R., BB 80. 30.5.1850.

33. Singapore Free Press, 26.9.1851. Microfilm. National Library, Singapore.

34. S.S.R., AA 22. 8.11.1851.

35. S.S.R., BB 91. 29.6.1853.

36. S.S.R., BB 80. 25.6.1850.

37. Singapore Free Press, 19.8.1853. Microfilm. National Library, Singapore.

38. S.S.R., W 19. 20.8.1853.

39. S.S.R., U 29. 18.4.1853. S.S.R., X 9. 24.4.1853.

40. S.S.R., W 22. 7.4.1856.

41. Singapore Free Press, 10.4.1856. Microfilm. National Library, Singapore.

42. S.S.R., W 22. 28.5.1856.

43. S.S.R., S 23. 31.10.1856.

44. S.S.R., R 21. 16.2.1857.

45. S.S.R., W 24. 7.5.1857.

46. S.S.R., Z 34. 2.12.1857.

47. S.S.R., W 26. 31.3.1858.

48. Singapore Free Press, 20.1.1859. Microfilm. National Library, Singapore.

49. S.S.R., B 111. 12.5.1859.

50. Singapore Free Press, 3.3.1859. Microfilm. National Library, Singapore.

51. Singapore Free Press, 5.5.1859. Microfilm. National Library, Singapore.

52. S.S.R., V 27. 28.9.1859.

53. S.S.R., V 29. 29.11.1859.

54. S.S.R., W 33. 27.2.1860.

55. S.S.R., W 34. 30.4.1860.

56. S.S.R., W 33. 9.4.1860. 
57. S.S.R., R 38. 9.10.1860.

58. Singapore Free Press, 24.1.1861. Microfilm. National Library, Singapore.

59. S.S.R., $X$ 21. 23.1.1861.

60. Singapore Free Press, 28.2.1861. Microfilm. National Library, Singapore.

61. S.S.R., X 21. 2.2.1861.

62. S.S.R., W 38. 23.5.1861.

63. S.S.R., W 39. 15.7.1861.

64. S.S.R., W 41. 15.1.1862.

65. S.S.R., W 42. 15.4.1862.

66. S.S.R., W 42. 30.4.1862.

67. S.S.R., X 23. 11.7.1863. S.S.R., U. 46 26.6.1863.

68. S.S.R., W 54 15.5.1865.

69. S.S.R., W 57. 1.5.1866.

70. S.S.R., V 40. 20.2.1865.

71. S.S.R., U 50. 24.3.1865.

72. S.S.R., U 50. 1.5.1865.

73. S.S.R., W 55. 18.10 .1865 .

74. S.S.R., R 43. 18.1.1867.

75. Daily Times, 7.3.1867. Microfilm. National Library, Singapore.

76. S.S.R., V 44. 12.3.1867.

77. S.S.D., COD/2. 18.12 .1867 .

78. S.S.D., GD/1. 5.6.1868.

79. Legislative Council Proceedings, 18.5.1868. Microfilm. National Library, Singapore.

80. S.S.D., COD/5. 12.11.1868.

81. S.S.D., COD/7. 7.7.1869.

82. S.S.R., HH 8. 11.8.1869.

Singapore Free Press (1835-1866). Microfilm. National Library, Singapore.

Straits Times (1845-1870). Microfilm. National Library, Singapore.

\section{SCOTTISH SOCIETY OF THE HISTORY OF MEDICINE}

At THE Annual General Meeting of the above Society, the following Office-Bearers were elected: President: Dr. T. R. R. Todd; Vice-President: Mr. C. G. Drummond, F.P.S.; Honorary Secretaries: Dr. H. P. Tait and Dr. A. H. B. Masson; Honorary Treasurer: Dr. W. D. H. Conacher; Members of Council: Dr. A. Jamieson, Dr. W. P. Kennedy, Mr. J. S. G. Blair, Dr. W. B. Howie, Sir Charles Illingworth, Dr. J. C. Shiach, Professor D. A. G. Waddell and Dr. P. Mackenzie. Dr. Tait and Dr. Masson were elected to represent the Society on the Council of the British Society for the History of Medicine.

The spring meeting of the Society will be held at 3.30 p.m. on 2 March 1973 in the Maurice Bloch Lecture Theatre, The Royal College of Physicians and Surgeons of Glasgow, when Mrs. Helen Brock will talk on 'James Douglas of the Pouch'. The summer meeting will be at Blantyre on 23 June 1973. Professor Shepperson will talk on 'Dr. David Livingstone'. 